\title{
Pemodelan Ciri Getaran Teoritik dan Eksperimental Berbasis Kerja Gaya pada Mesin Reciprocating
}

\author{
Fransiskus Louhenapessy' ${ }^{1}$, Achmad Zubaydi², $^{2}$ Suhardjono ${ }^{3}$, \\ I. Made Ariana ${ }^{4}$, A.A. Masroeri ${ }^{5}$ \\ 1,2,3. Program Studi Teknik Mesin ITS, Surabaya \\ 3,45. Fakultas Teknologi Kelautan ITS, Surabaya \\ E-mail: frans@na.its.ac.id
}

\begin{abstract}
ABSTRAK
Penelitian ini bertujuan untuk memodelkan ciri respon getaran teoritik dan eksperimental berbasis kerja gaya dari komponen dinamik pada reciprocating mesin. Metode yang digunakan adalah menganalisis gaya yang terakumulasi pada main bearing secara teoritik, melakukan rekonstruksi sinyal getaran eksperimental serta validasi. Pemodelan gaya melibatkan proses kompresi yang menyebabkan adanya gaya kompresi dan gaya inersia. Analisis menggunakan formulasi matematis dari Newton yang direkayasa sehingga menghasilkan gaya dinamik. Hasil penelitian mengindikasikan bahwa gaya total maksimum terakumulasi pada main bearing 194.4 $\mathrm{N}$ arah vertikal dan $29.7 \mathrm{~N}$ arah horizontal. Hasil analisis sinyal getaran teoritik dan eksperimental divalidasikan dengan terlebih dahulu merekonstruksi sinyal getaran eksperimental, dalam domain waktu dan frekuensi untuk menghilangkan sinyal noise dengan menggunakan software Matlab. Hasil dari proses validasi diperoleh clearance main bearing $\mathrm{C}_{1}=60 \mu \mathrm{m}$, nilai ini sesuai dengan hasil pengukuran dimensi clearance bearing secara manual. Pemodelan ciri getaran ini dapat digunakan untuk perawatan mesin berbasis pemantauan sinyal getaran terjadwal.
\end{abstract}

Kata kunci: Ciri getaran, bearing, poros engkol, frekuensi, clearance.

\begin{abstract}
This study aims to model vibration response characteristics of theoretical and experimental work based force of dynamic components in reciprocating mesins. The method used was to analyze force that accumulates on main bearing area of theoretical, experimental vibration signal reconstruction and validation. Modeling involves process compression force that causes compression force and inertia force. The analysis uses a mathematical formulation of Newton are mesinered to produce a dynamic force. Results indicate that maximum total force accumulated in main bearing is $194.4 \mathrm{~N}$ and $29.7 \mathrm{~N}$ vertical direction and horizontal direction. Results of analysis theoretical and experimental vibration signals are validated by first reconstructing experimental vibration signal, in time domain and frequency to eliminate noise signals using Matlab software. Results of the validation process obtained clearance to bearing $C 1=60 \mu \mathrm{m}$, this value is accordance with measurement of bearing clearance dimensions manually. Modelling vibration characteristics can be used for treatment of mesin vibration signal monitoring based on scheduled.
\end{abstract}

Keywords: Characteristic vibration, bearing, poros engkol, frequency, clearance.

\section{PENDAHULUAN}

Ciri Getaran yang dihasilkan dari reciprocating mesin diakibatkan oleh kerja gaya-gaya dinamik, gaya ini terakumulasi pada main bearing penumpu poros engkol. Pemodelan ciri getaran teoritik maupun eksperimental didasari pada jenis gaya pada saat reciprocating seperti gaya kocokan (shaking) [1]. Penelitian ini bertujuan untuk memodelkan ciri getaran teoritik dan eksperimental berbasis kerja gaya pada reciprocating mesin, dengan clearance pada bearing melebihi standar pabrik pembuat mesin. Gaya dinamik yang dibangkitkan oleh komponen dinamik, serta gaya kompresi dihitung secara numerik yang terakumulasi pada main bearing.

\section{METODE PENELITIAN}

Metodologi yang digunakan mulai dari awal penelitian sampai penulisan jurnal ini diperlihatkan dalam flow chart seperti Gambar 1. 


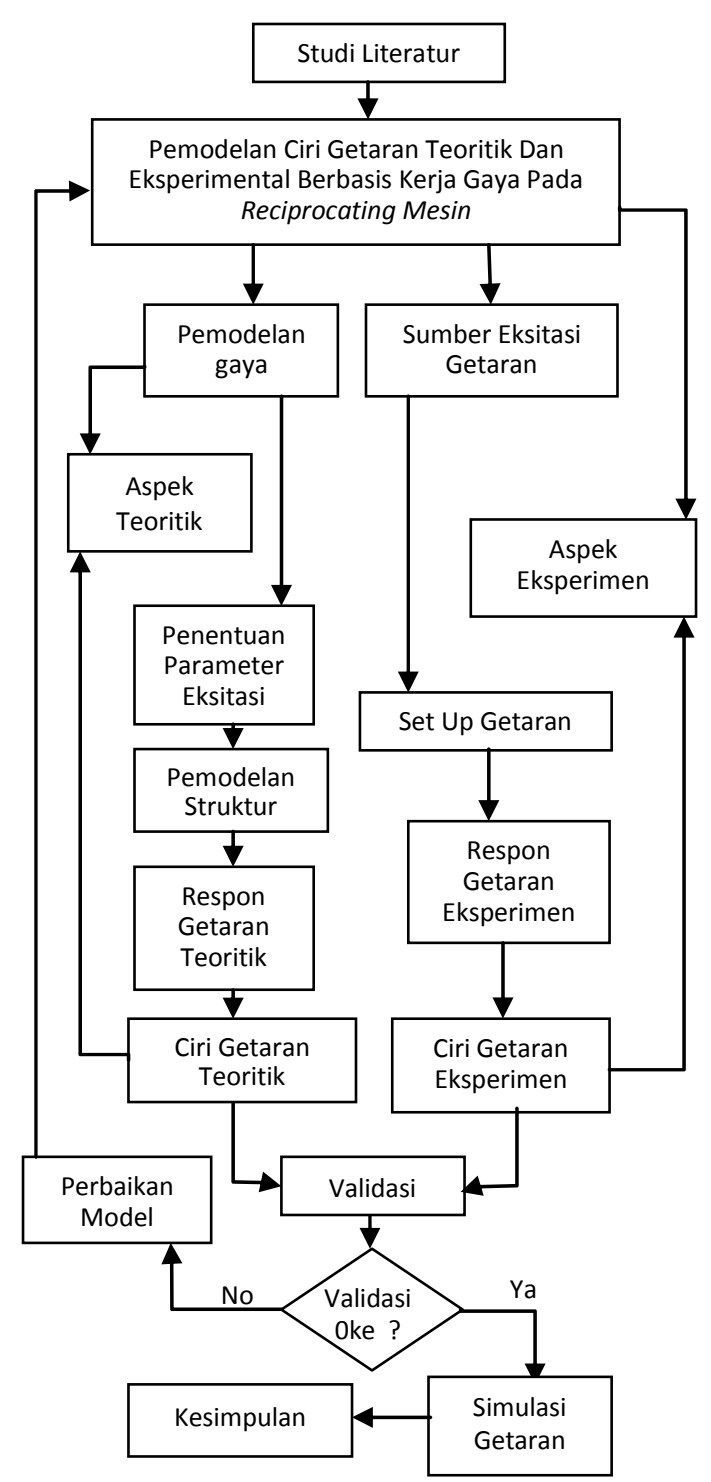

Gambar 1. Diagram Alir Penelitian

Analisis dinamis pengaruh kelonggaran komponen joint terhadap ciri getaran diperlukan model matematika teknik dengan resolusi tinggi, sehingga hasil validasi ciri getaran teoritik terhadap ciri getaran eksperimental sebanding atau sama.

\section{HASIL DAN PEMBAHASAN}

\section{Getaran Mesin Teoritik}

Mesin pada saat beroperasi menimbulkan getaran yang disebabkan oleh adanya gaya secara siklus dari komponen dinamik dan gaya akibat combustion. Getaran pada mesin dapat dimodelkan dengan persamaan banyak derajat kebebasan (multiple degreeof freedom ) sebagai berikut [2]:

$$
[M]\{\ddot{x}(t)\}+[C]\{\dot{x}(t)\}+[K]\{x(t)\}=\{F(t)\}
$$

Persamaan 1 adalah getaran bebas dengan komponen yang terdiri dari matriks massa, redam- an, kekakuan dan gaya stimulus. Digunakan untuk menentukan level ampiltudo percepatan getaran mesin akibat gaya yang bekerja. $\{\mathrm{F}(\mathrm{t})\}$ dalam persamaan di atas mengindikasikan bahwa gaya berasal dari combustion dan gaya inersia dari komponen dinamik mesin, dapat di analisis sebagai berikut.

\section{Gaya Kompresi}

Gaya kompresi untuk motor 2 langkah terjadi pada $\pm 121^{\circ}$ engkol yang dapat menghasilkan tekanan reta-rata ( $\mathrm{P}_{\text {rata-rata) }}$ yang sangat dibutuhkan untuk terjadinya pembakaran yang sempurna seperti Gambar 2 [3].
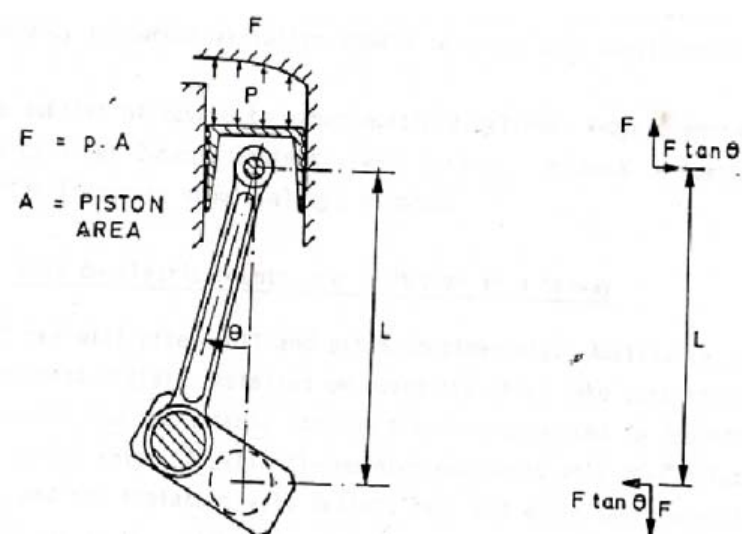

Gambar 2. Posisi Mesin pada Langkah Kompresi

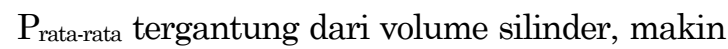
kecil ruang silinder tekanan makin besar, dengan tekanan ini dapat dihitung gaya akibat kompresi [4] sebagai berikut:

$$
P_{\text {rata - rata }}=\frac{N_{i} \cdot 450000}{V_{L} \cdot \text {. } \cdot \text {.n.a }}
$$

$\mathrm{N}_{\mathrm{i}}$ adalah daya indikator yang tergantung dari $\mathrm{N}_{\mathrm{e}}=$ 5 PS sebagai daya efektif dan efisiensi indikator $\eta_{\mathrm{i}}$. $\mathrm{V}_{\mathrm{L}}$ adalah volume silinder tergantung dari $\mathrm{L}$ adalah panjang langkah, $0.785 \mathrm{~d}^{2}$ adalah luas silinder, $\mathrm{z}=1$ jumlah silinder, $\mathrm{n}=5000 \mathrm{rpm}$ dan $\mathrm{a}=1$ adalah koefisien siklus mesin dua langkah. Dengan Persamaan 2 diperoleh tekanan $\mathrm{P}_{\text {rata-rata }}$ selanjutnya dikalkulasikan gaya kompresi adalah:

$$
F_{k}=\frac{\pi}{4} d^{2} P_{\text {rata-rata }}
$$

Persamaan 3 adalah besarnya gaya akibat kompresi yang terjadi pada langkah kompresi dimana d adalah diameter silinder.

\section{Gaya Akibat Clearance Main Bearing}

Gaya inersia yang berasal dari piston dan connecting rod akan diteruskan ke crank-pin dan shaft kemudian diteruskan ke bantalan utama. 


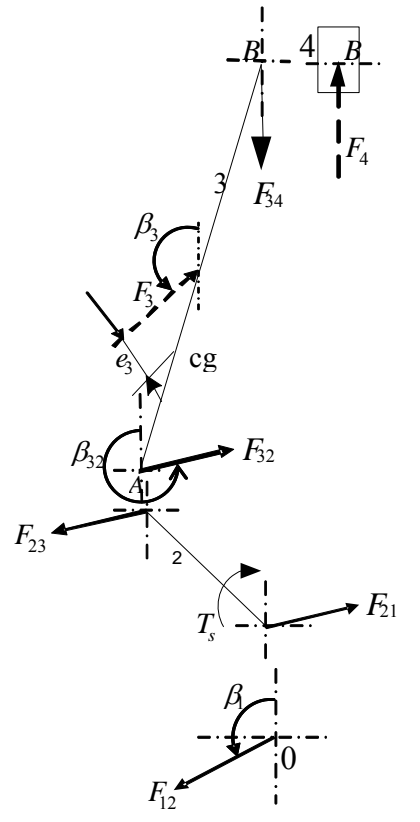

Gambar 3. Diagram Bodi Bebas

Penurunan gaya dari DBB seperti dalam Gambar 3 adalah sebagai berikut, $\vec{F}_{34}=-\vec{F}_{4}$, vektor gaya ini mengidikasikan vektor $\vec{F}_{34}$ sama besarannya dengan vektor $\vec{F}_{4}$ dengan arah yang berlawanan, memenuhi persyaratan hukum Newton ke 3. $\vec{F}_{23}=-\vec{F}_{32}$, vektor $\vec{F}_{23}$ sama besarnya dengan vektor $\vec{F}_{32}$ dengan arah yang berbeda. Selanjutnya $\vec{F}_{21}=-\vec{F}_{23}=\vec{F}_{32}, \quad \vec{F}_{12}=-\vec{F}_{21}$, yang bekerja pada bantalan utama.

Pemodelan ini melibatkan gaya inersia, gaya berat dari seluruh komponen mesin yang bergerak dan gaya kompresi yang diurutkan dari torok sampai ke bantalan utama. Penentuan respon getaran dengan memasukan gaya kompresi $\mathrm{F}_{\mathrm{k}}$ [4], poros engkol bergerak berputar sedangkan outer race bearing tidak bergerak atau statik sehingga bantalan dapat dianggap sebagai bidang sleeve.

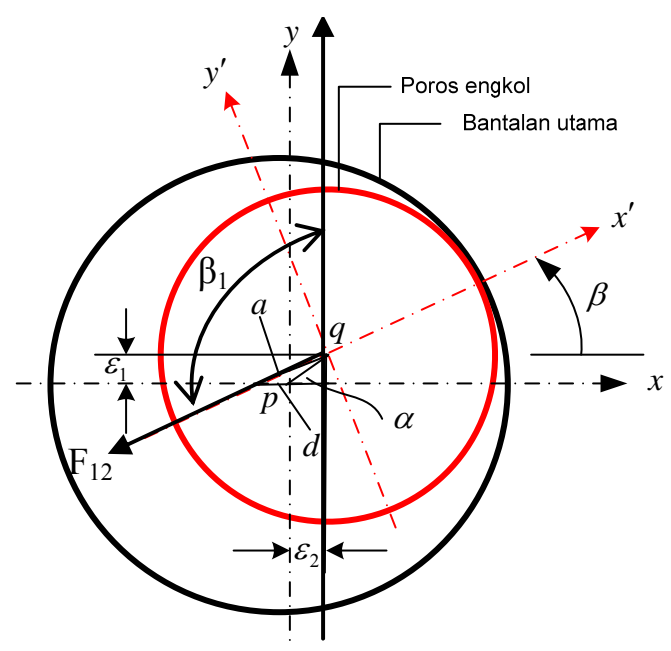

Gambar 4. Diagram Kinematika Bantalan Utama
Pada Gambar 4 terlihat bahwa posisi poros menyentuh bantalan sehingga celah pada posisi ini mencapai maksimum, maka dapat dihitung $\mathrm{F}_{12}$ dengan persamaan rekayasa berikut,

$$
\vec{F}_{12}=\sqrt{F_{k}^{2}+{F_{23}^{\prime}}^{2}-2 \vec{F}_{k} F_{23}^{\prime} \cos \left(\frac{\pi}{2}-\sin \left(\cos \left(\tan ^{-1} \frac{F_{32}}{F_{23}}\right)\right)-\cos \left(\frac{1}{2} \alpha\right)\right)}
$$

Gaya yang bekerja pada bantalan utama pada arah vertikal dan horizontal berasal dari gaya kompresi, gaya inersia torak dan connecting rod sebagai berikut:

$$
\begin{aligned}
& F_{x}=F_{12} \sin \left(\pi-\beta_{1}\right) \\
& F_{y}=F_{12} \cos \left(\pi-\beta_{1}\right)
\end{aligned}
$$

Dimana $\beta_{1}=\beta_{32} \pm \pi\left(+j i k a \beta_{32}<\pi\right.$ dan sebaliknya)

Persamaan 4, 5 dan 6 adalah besarnya gaya yang bekerja pada bantalan utama dengan $B_{1}$ adalah sudut yang dibentuk oleh vektor gaya $\mathrm{F}_{12}$ dengan sumbu real seperti Gambar 3 dan 4.

\section{Gaya Berat Sistem Poros engkol}

Gaya akibat berat komponen sistem poros engkol yang bekerja pada bantalan utama pada titik A dan B dimodelkan seperti Gambar 5. Pemodelan gaya berat komponen poros engkol yang terdiri dari shaft, web dan flywheel diperlukan karena pada keadaan statik maupun dinamik gaya ini bekerja pada bantalan utama pendukung poros engkol. Pada tumpuan A dan B bekerja gaya dari poros engkol dan flywheel sehingga timbul gaya reaksi tumpuan $\mathrm{F}_{\mathrm{R} 1}$ dan $\mathrm{F}_{\mathrm{R} 2}$.

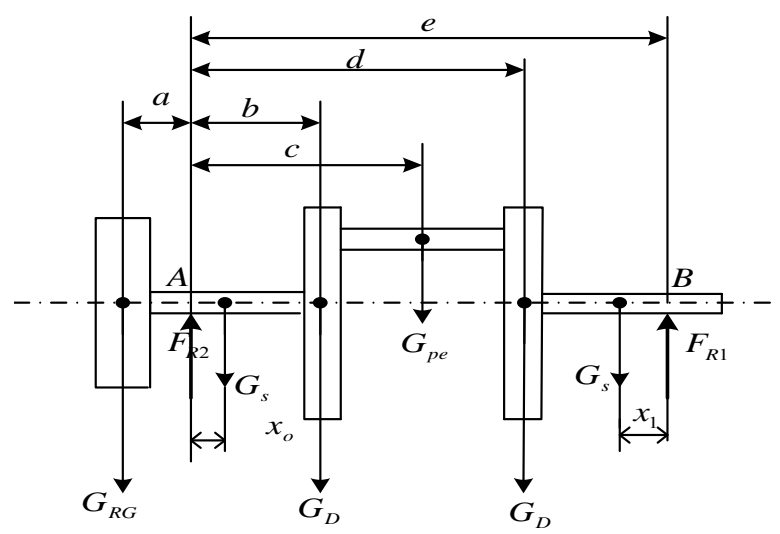

Gambar 5. Model Komponen Sistem Poros Engkol

Gaya berat komponen mesin jumlahnya tergantung dari banyaknya komponen dinamik, gaya berat $\mathrm{F}_{\mathrm{R} 1}$ yang bekerja pada titik $B$ dihitung dengan Persamaan 7 [5], sebagai berikut:

$$
\begin{gathered}
G_{R g}(e+a)+G_{1}\left(e-x_{o}\right)+G_{D 1}(e-b) \\
F_{R 1}=\frac{+G_{p e}(e-c)+G_{D 2}(e-d)+G_{2}\left(e-x_{1}\right)}{e_{A B}}
\end{gathered}
$$


Dengan model yang sama gaya berat $\mathrm{F}_{\mathrm{R} 2}$ yang bekerja pada titik A dapat dihitung, jarak e dari tumpuan A ke tumpuan B pada bantalan utama tempat diletakan sensor getaran dapat ditentukan dengan Persamaan 8 yang merupakan pengembangan dari persamaan Giancarlo Genta [2] sebagai berikut,

$$
\begin{gathered}
e_{A B}=2 c+0.15 D+\frac{\left(a+0.15 D\left(D^{4}\right)\right)}{D^{4}}+\left[2 b-0.15\left(D+D^{\prime}\right)\right] \frac{D^{4}}{d_{w}{ }^{4}}+ \\
r\left(0.065 \frac{D}{b}+0.58\right) \frac{D^{4}}{b d_{w}{ }^{3}}+0.16 \frac{D^{4}}{b^{2} d_{w}}
\end{gathered}
$$

\section{Gaya Inersia Sistem Poros engkol}

Sistem poros engkol meliputi flywheel dan crankweb mempunyai bentuk disk dan terpasang pada poros. Pada saat poros berputar, crank-web dan flywheel turut berputar seperti terlihat pada Gambar 6 flywheel (3) dan crankweb (2) terpasang pada poros (1) sehingga kecepatan angular kedua disk sama besar [5], [6].

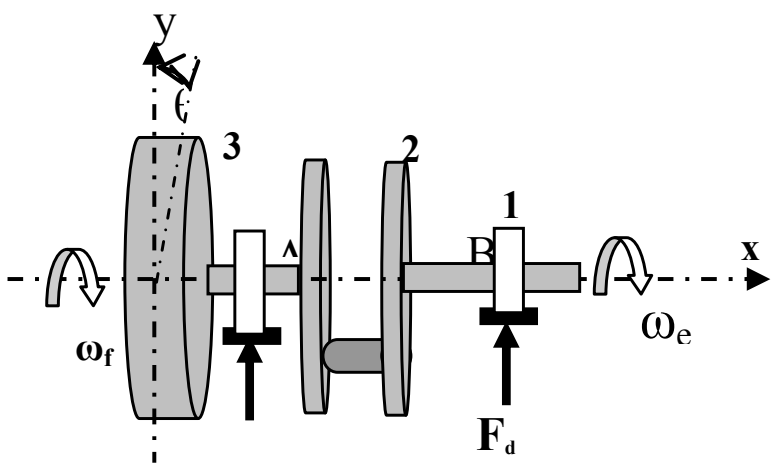

Gambar 6. Model Komponen Sistem Poros Engkol

Gaya inersia dinamik kedua disk dapat ditentukan dengan perhitungan torsi dari komponen web dan flywheel yang bekerja pada main bearing terpusat pada titik B sebagai berikut:

$$
F_{d}=\frac{\tau_{d}}{e_{A B}}
$$

$\tau_{d}$ pada Persamaan (9) adalah torsi inersia yang dihitung dengan persamaan $\tau_{d}=I_{d} a$ dimana $I_{d}=$ $1 / 2 m_{d} r_{d}^{2}, m_{d}$ adalah massa disk web dan $r_{d}$ adalah jari-jari web disk dan a adalah kecepatan sudut. Gaya total yang bekerja pada bantalan utama yang menyebabkan mesin bergetar dengan amplitudo percepatan yang berfluktuasi, dihitung dengan Persamaan 10 dinyatakan sebagai persamaan respon getaran mesin.

$$
[M]\{\ddot{x}(t)\}+[C]\{\dot{x}(t)\}+[K]\{x(t)\}=\left\{F_{12}(t)+F_{d}(t\}\right\}
$$

Persamaan 10 adalah hasil rekayasa gaya yang bekerja pada bantalan utama, yang disebut sebagai persamaan sebab akibat, yang membuat mesin bergetar dengan amplitudo dalam m/detik ${ }^{2}$. Subtitusi Persamaan 5 dan 6 ke Persamaan 9 menghasilkan dua persamaan dinamik, yaitu Persamaan 11 adalah getaran mesin arah horizontal dan Persamaan 12 adalah persamaan getaran arah vertikal.

$$
\begin{aligned}
& {[M]\{\ddot{x}(t)\}+[C]\{\dot{x}(t)\}+[K]\{x(t)\}=\left\{F_{x}(t)+F_{d x}(t)\right\}} \\
& {[M]\{\ddot{x}(t)\}+[C]\{\dot{x}(t)\}+[K]\{x(t)\}=\left\{F_{y}(t)+F_{d y}(t)\right\}}
\end{aligned}
$$

\section{Aspek Simulasi Komputasional}

Gaya pada Main Bearing Hasil Simulasi Kompu$\underline{\text { tasional }}$

Gaya yang bekerja pada bantalan utama dianalisis dalam arah vertikal dan horizontal, dan hasilnya seperti pada Gambar 7 dan 8. Gaya pada bantalan utama terdiri dari gaya inersia dan kompresi yang dihitung dengan Persamaan 5 dan 6 .

Besarnya gaya maksimum $165 \mathrm{~N}$ pada arah vertikal seperti diperlihatkan pada Gambar 8. Dan $25 \mathrm{~N}$ pada arah horizontal seperti Gambar 8, yang membebani poros engkol sehingga mengakibatkan adanya getaran yang terdistribusi ke seluruh badan mesin [8].

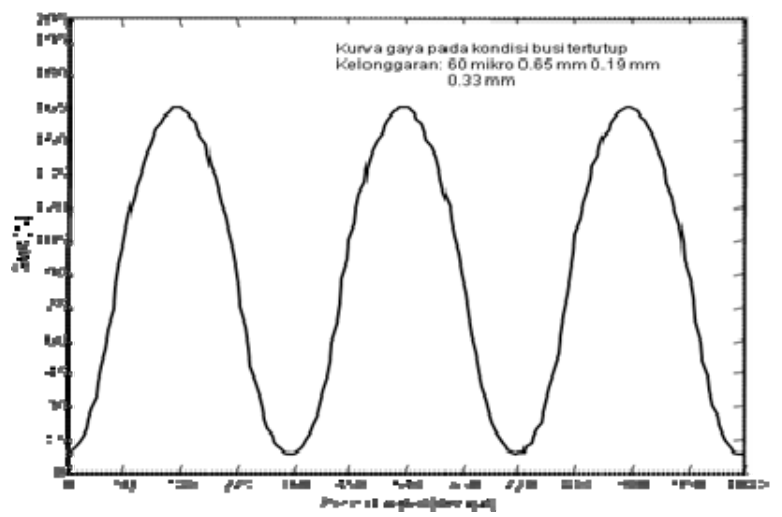

Gambar 7. Gaya pada Bantalan Utama pada Arah Vertikal

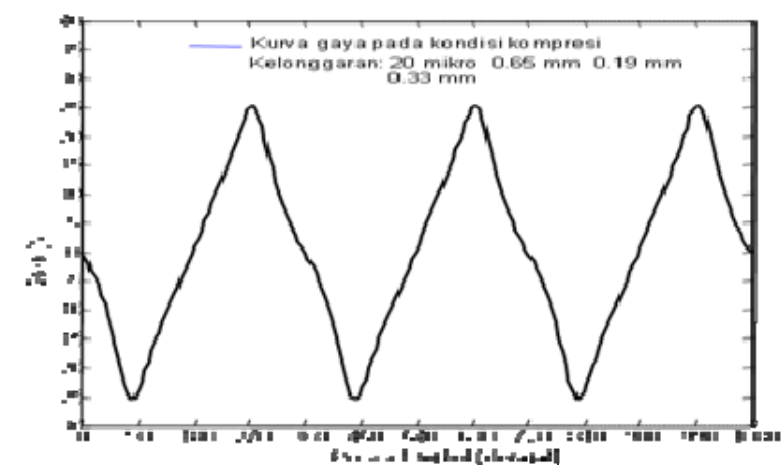

Gambar 8. Grafik Gaya pada Main Bearing Arah Horizontal 


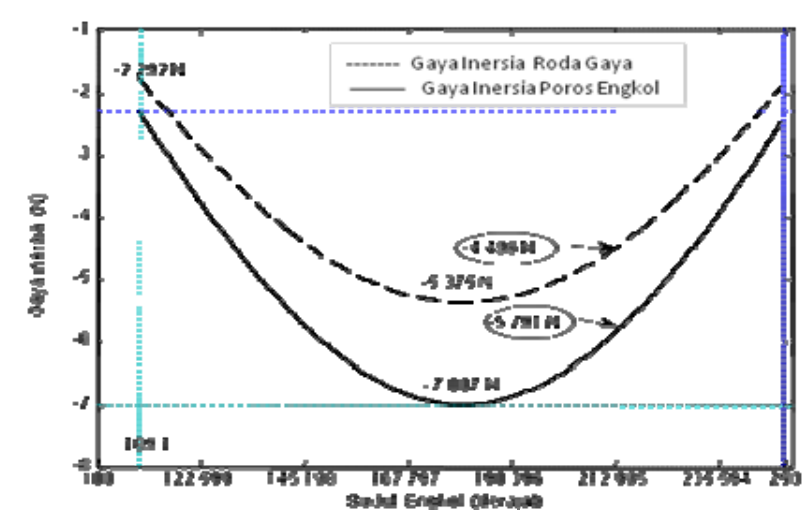

Gambar 9. Gaya Inersia Dinamik Total dari Flywheel dan Crankweb

Kurva gaya pada bantalan disimulasikan dengan variasi celah pada bantalan utama $\mathrm{C}_{1}=0.60$ $\mu \mathrm{m}$ yang dihitung, gudgeon-pin besar $\mathrm{C}_{2}=0.65 \mathrm{~mm}$, gudgeon-pin kecil $\mathrm{C}_{3}=0.19 \mathrm{~mm}$ dan silinder terhadap torak $\mathrm{C}_{4}=0.33 \mathrm{~mm}$.

\section{Gaya Berat dan Dinamik Crank shaft}

Gaya akibat berat komponen sistem poros engkol dan flywheel dihitung dengan Persamaan 9, dengan model seperti Gambar 5 dan 6, besar gaya berat total dari komponen dinamis, yang bekerja pada main bearing pada tumpuan B adalah 17.007 N. Gaya ini dihitung dengan menggunakan simulasi komputasional.

Dari Gambar 9 dapat dilihat bahwa besarnya gaya inersia maksimum crankweb adalah $7.007 \mathrm{~N}$, sedangkann flywheel adalah 5.375 N. Kedua gaya tersebut memiliki tanda minus karena poros engkol mengalami gaya tekan ke bawah. Total gaya hasil analisis dan simulasi komputasional sebesar 194.4 $\mathrm{N}$ arah vertikal dan $29.7 \mathrm{~N}$ pada arah horizontal.

\section{Aspek Eksperimental}

\section{$\underline{\text { Set Up Pengujian Getaran Mesin }}$}

Mesin yang digunakan dalam eksperimental getaran mempunyai daya $5 \mathrm{HP}$, putaran $5000 \mathrm{rpm}$, dan 2 langkah silinder tunggal. Mesin digerakan oleh motor $\mathrm{AC}$, dinama $\mathrm{F}_{\mathrm{k}}$ adalah gaya kompresi yang bekerja pada piston. Gambar 10 memperlihatkan set up Pengujian getaran mesin. Badan mesin disekitar poros engkol diasumsikan sebagai rumah bantalan karena ditempatkan bantalan utama pendukung poros engkol [7].

Accelerometer digunakan untuk mengukur respon getaran pada arah vertikal dan horizontal. Converter digunakan untuk mengatur putaran mesin dengan mengubah putaran motor penggerak. Optical key phasor digunakan sebagai pembangkit pulsa selama pengukuran getaran. Charge amplifier digunakan untuk mengkondisikan sinyal peng- ukuran getaran oleh accelerometer. Multi channel analyzer berfungsi untuk mengolah sinyal pengukuran untuk mendapatkan waveform dan spektrum frekuensi.

Respon Getaran Eksperimental Domain Waktu $\underline{\text { Arah Vertikal dan Horizontal }}$

Kurva respon getaran berupa percepatan amplitudo dalam domain waktu pada arah horizontal seperti Gambar 11 dihitung dengan Persamaan 11 dan 12.

Gambar 11 juga memiliki sifat fisik dan dinamik pada posisi ukur arah vertikal dengan amplitudo maksimum $9 \mathrm{~m} /$ detik $^{2}$ dan murni hasil pengujian getaran sebelum di rekonstruksi.

Seperti halnya dengan percepatan amplitudo ke arah vertikal, maka pada Gambar 12 dapat dilihat bahwa gaya dinamik juga menghasilkan percepatan amplitudo dimana harga maksimum pada arah horizontal mendekati $6.5 \mathrm{~m} /$ detik $^{2}$ dan 4.5 $\mathrm{m} /$ detik $^{2}$ terjadi pada putaran ke dua, tiga dan empat.

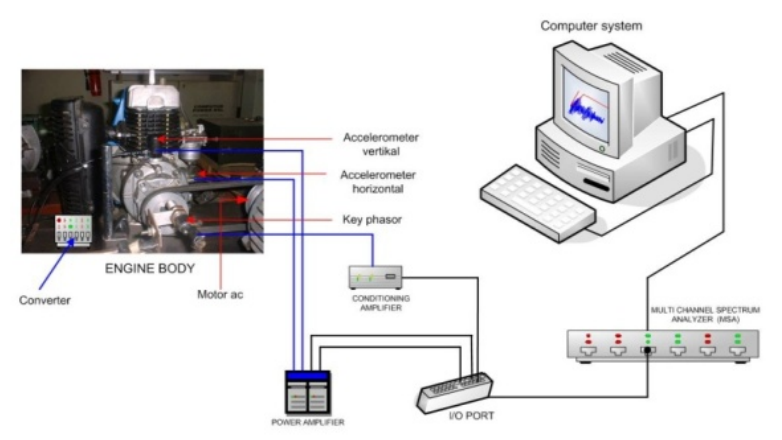

Gambar 10. Set up Pengujian Getaran Mesin

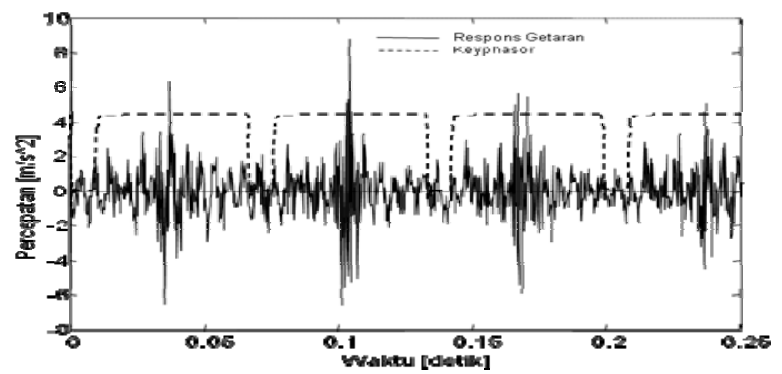

Gambar 11. Kurva Respon Percepatan Vertikal sebelum Direkonstuksi

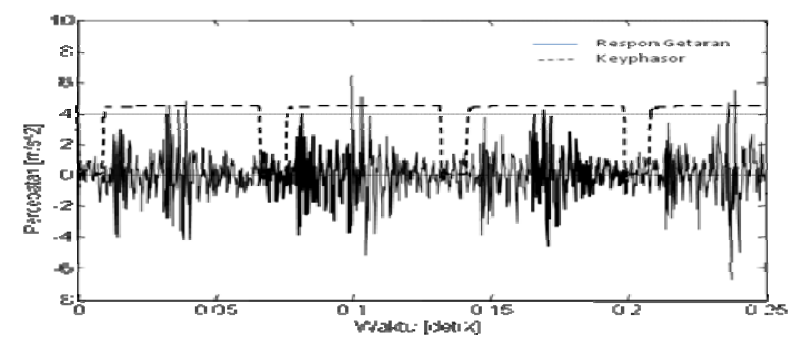

Gambar 12. Kurva Respon Percepatan Horizontal sebelum Direkostruksi 
Respon Getaran Domain Frekuensi Arah Horizontal $\underline{\text { dan Vertikal }}$

Untuk menganalisis kerusakan atau kesalahan pada komponen bantalan utama, maka percepatan amplitudo hasil percobaan dalam bentuk domain frekuensi seperti terlihat pada Gambar 13 pada arah horizontal. Gambar 14 adalah amplitudo pada arah vertikal untuk putaran web 900 rpm. Percepatan amplitudo terbesar mendekati 0.275 $\mathrm{m} /$ detik $^{2}$ dan terjadi pada putaran $75 \mathrm{~Hz}$ pada pengukuran horizontal. Percepatan amplitudo tertinggi berada pada $\mathrm{n}=7200$ putaran web. Sedangkan percepatan amplitudo lainnya merupakan ciri getaran dari sifat fisik bantalan utama pada arah vertikal.

Waveform dan spektrum frekuensi lain yang muncul dapat diasumsikan sebagai ciri getaran yang berasal dari sifat fisik bantalan gelinding, seperti ball pass frequency outer, ball pass frequency inner race, ball spin frequency, fundamental train frequency.

Akibat dari banyaknya sinyal yang di rekam oleh accelerometer, maka diadakan rekonstruksi.

\section{Aspek Rekonstruksi Sinyal Getaran}

\section{Rekonstrusi Sinyal Hasil Eksperimental}

Sinyal getaran hasil eksperimental seperti Gambar 11 dan 12 di analisis menggunakan persamaan yang direkayasa, kemudian disimulasikan pada program Matlab [8]. Persamaan 13 dan 14 berlaku untuk rekonstruksi sinyal getaran arah horizontal dan vertikal.

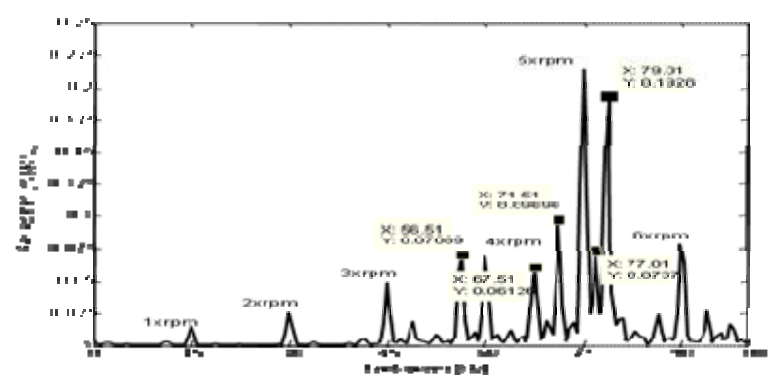

Gambar 13. Kurva Respon Frekuensi Horizontal

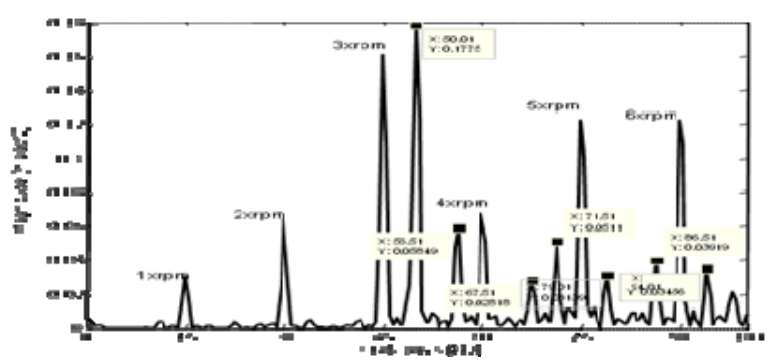

Gambar 14. Kurva Respon Frekuensi Vertikal

$$
\begin{aligned}
& R_{x}=m_{h} \cos (\omega t)+\phi_{h} \\
& R_{y}=m_{v} \cos (\omega t)+\phi_{v}
\end{aligned}
$$

Persamaan 13 dan 14, dimana $m_{h}$ adalah magnitude amplitudo percepatan dari getaran dalam $\mathrm{m} /$ detik $^{2} \omega t$ adalah perkalian antara kecepatan putar engkol dengan $t$ sebagai waktu $\omega$ kecepatan sudut. $\Phi_{h}$ adalah sudut phase horizontal dan $\Phi_{v}$ adalah sudut phase vertikal.

Waveform hasil rekonstrusi ini adalah sinyal murni berasal dari kerjanya komponen mesin yang terukur pada arah vertikal dan horizontal dan bersih terhadap sinyal gangguan. Gambar 15 teramati bahwa sinyal tidak cosinus murni, tetapi terdapat sinyal super posisi dengan amplitudo pada kisaran dari 0 sampai $0.135 \mathrm{~m} / \mathrm{sec}^{2}$ untuk percepatan pada arah horizontal, terjadi pada satu putaran poros engkol dengan waktu 0.05 detik.

Gambar 16 adalah kurva sinyal getaran yang diakibatkan oleh gaya kocokan arah vertikal (ke arah atas dan arah ke bawah), dengan bentuk sinusoidal. Pada 1 putaran engkol dengan waktu 0.05 detik pada diameter shaft $\Phi=25 \mathrm{~mm}$ terjadi tiga gelombang sinusoidal, amplitudo mencapai 0.78 $\mathrm{m} /$ detik $^{2}$. Waveform hasil rekonstruksi seperti inilah yang digunakan sebagai sinyal referensi untuk divalidasikan. Sinyal hasil rekonstruksi dalam domain frekuensi seperti Gambar 17 diperoleh percepatan amplitude mencapai $0.14 \mathrm{~m} / \mathrm{detik}^{2}$, pada frekuensi $45 \mathrm{~Hz}$ untuk pengukuran arah vertikal. Sinyal hasil rekonstruksi seperti dalam Gambar 18 diperoleh percepatan amplitude mencapai 0.02 $\mathrm{m} /$ detik $^{2}$ pada $75 \mathrm{~Hz}$.

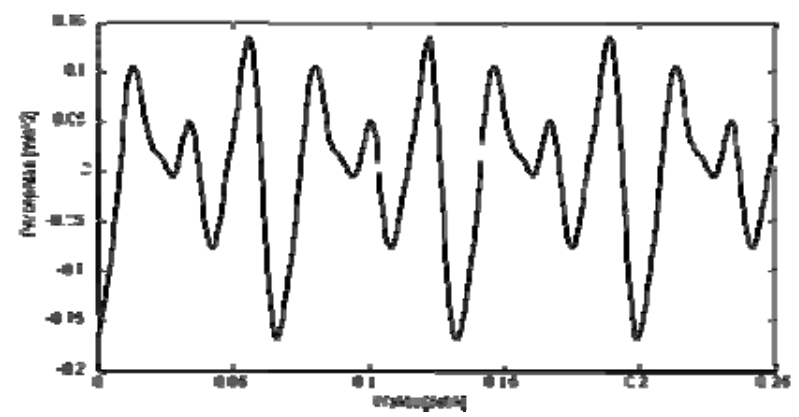

Gambar 15. Kurva Respon Frekuensi Horizontal Hasil Rekonstruksi

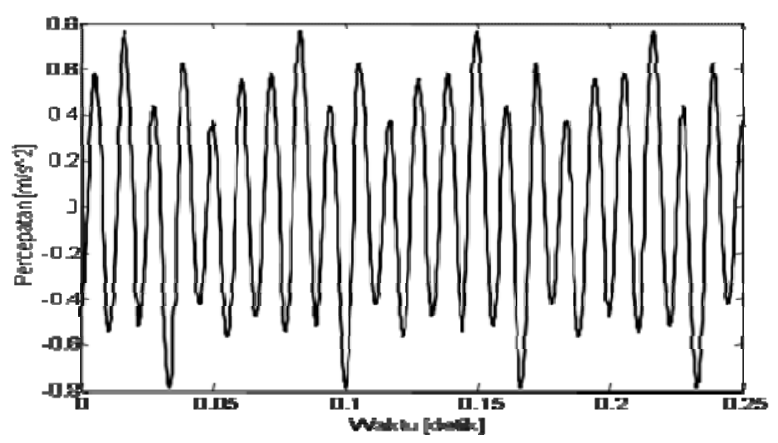

Gambar 16. Kurva Respon Frekuensi Vertikal Hasil Rekonstruksi 


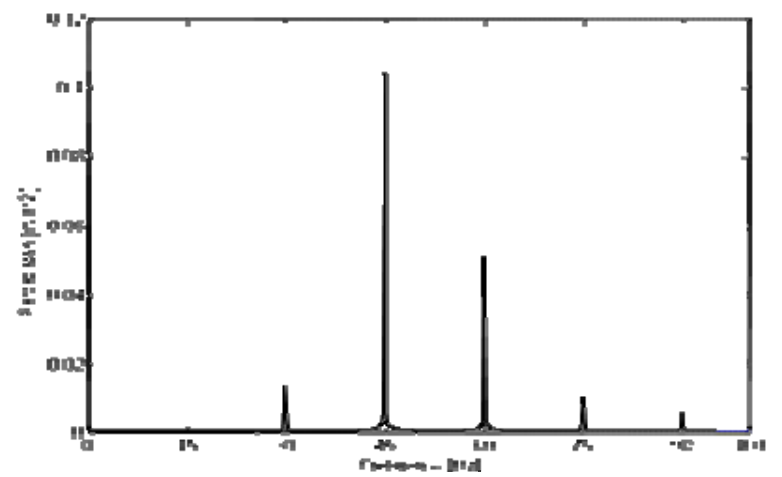

Gambar 17. Kurva respon frekuensi horizontal

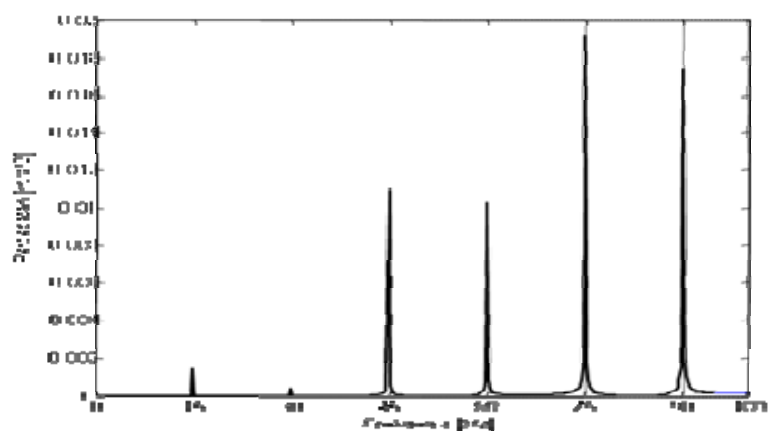

Gambar 18. Kurva Respon Frekuensi Vertikal

\section{Aspek Validasi Getaran Teoritik Dengan Eksperimental}

\section{Validasi Respon Getaran Mesin}

Sinyal getaran hasil analisis teoritik divalidasikan dengan sinyal getaran eksperimental hasil rekonstruksi menggunakan simulasi komputasional Matlab untuk respon percepatan horizontal dan vertikal. Validasi dilakukan untuk mendapatkan nilai celah pada bantalan utama. Kurva simpangan casing dalam arah $\mathrm{X}$ diperoleh dengan mengembangkan fungsi deret Fourier sampai orde ke 7 untuk arah pengukuran horizontal sebagai berikut,

$$
\begin{aligned}
\frac{d^{2}}{d t^{2}} X_{c}(t)= & -a_{h 1} \omega^{2} \sin (\omega t)-4 a_{h 2} \omega^{2} \sin (2 \omega t)-9 a_{h 3} \omega^{2} \sin (3 \omega t)-16 a_{h 4} \omega^{2} \sin (4 \omega t)- \\
& 25 a_{h 5} \omega^{2} \sin (5 \omega t)-36 a_{h 6} \omega^{2} \sin (6 \omega t)-49 a_{h 7} \omega^{2} \sin (7 \omega t)- \\
& b_{h 1} \omega^{2} \cos (\omega t)-4 b_{h 2} \omega^{2} \cos (2 \omega t)-9 b_{h 3} \omega^{2} \cos (3 \omega t)-16 b_{h 4} \omega^{2} \cos (4 \omega t)- \\
& 25 b_{h 5} \omega^{2} \cos (5 \omega t)-36 b_{h 6} \omega^{2} \cos (6 \omega t)-49 b_{h 7} \omega^{2} \cos (7 \omega t)
\end{aligned}
$$

Kurva simpangan arah $\mathrm{X}$ didekati dengan fungsi deret Fourier seperti Persamaan 15, untuk respons percepatan y dapat diperoleh dengan Persaman 16.

$$
\begin{aligned}
\frac{d^{2}}{d t^{2}} Y_{c}(t)= & -a_{v 1} \omega^{2} \sin (\omega t)-4 a_{v 2} \omega^{2} \sin (2 \omega t)-9 a_{v 3} \omega^{2} \sin (3 \omega t)-16 a_{v 4} \omega^{2} \sin (4 \omega t)- \\
& 25 a_{v 5} \omega^{2} \sin (5 \omega t)-36_{v 6} \omega^{2} \sin (6 \omega t)-49_{v 7} \omega^{2} \sin (7 \omega t)- \\
& \left.\left.b_{v 1} \omega^{2} \operatorname{co}(\omega t)-4 b_{v 2} \omega^{2} \operatorname{co}(2 \omega t)-9 b_{v 3} \omega^{2} \operatorname{co} \$ 3 \omega t\right)-16_{v 4} \omega^{2} \operatorname{co} \$ 4 \omega t\right)- \\
& \left.\left.25_{v 5} \omega^{2} \operatorname{co}(5 \omega t)-36_{v 6} \omega^{2} \operatorname{co} \$ 6 \omega t\right)-49_{v 7} \omega^{2} \cos \$ 7 \omega t\right)
\end{aligned}
$$

Untuk melakukan proses validasi antara sinyal getaran teoritik dan sinyal getaran hasil rekon- struksi maka diperlukan nilai koefisien Fourier untuk arah pengukuran horizontal dan vertikal. Validasi dilakukan dengan variasi celah untuk bantalan utama $\mathrm{C}_{1}=0.60 \mu \mathrm{m}$, gudgeon-pin besar $\mathrm{C}_{2}$ $=0.65 \mathrm{~mm}$, gudgeon-pin kecil $\mathrm{C}_{3}=0.19 \mathrm{~mm}$ dan silinder terhadap torak $\mathrm{C}_{4}=0.33 \mathrm{~mm}$.

\section{Validasi Respon Getaran Mesin Teoritik Dan Eksperimental}

Keausan pada komponen mekanisme penyambung mesin yang bergerak akan merubah pola gerak dari masing-masing komponen mesin seperti yang diperoleh dalam Gambar 19.

Terlihat dari Gambar 19 dan 20 di mana respon kajian teoritik di validasi dengan respon kajian hasil pengukuran eksperimental yang direkonstruksi maka terdapat perbedaan phase. Dan percepatan khusus pada respon arah horisontal dan vertikal terbesar adalah 0.17 dan $0.79 \mathrm{~m} / \mathrm{sec}^{2}$.

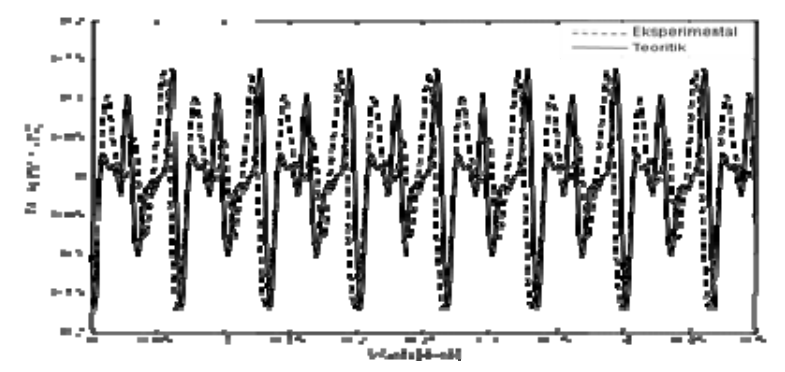

Gambar 19. Kurva Respon Frekuensi Horizontal Hasil Validasi

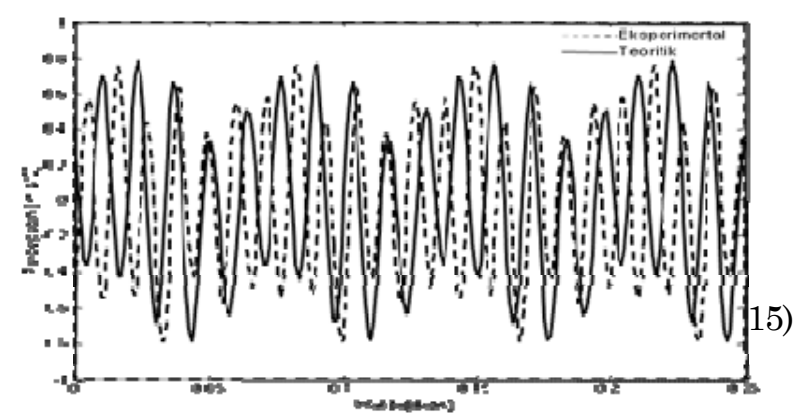

Gambar 20. Kurva Respon Frekuensi Vertikal Hasil Validasi

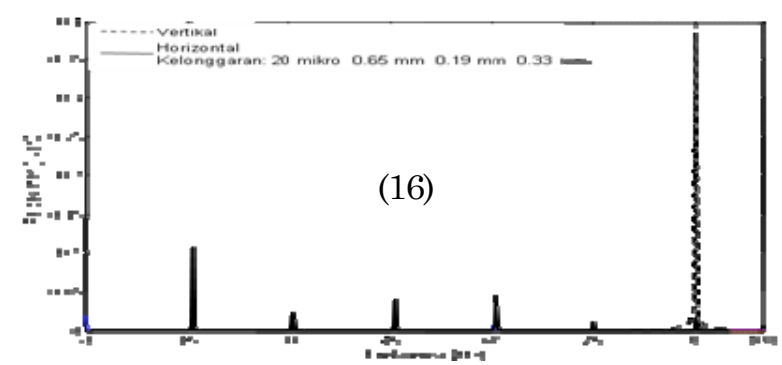

Gambar 21. Kurva Respon Horizontal dan Vertikal Hasil Validasi 
Gambar 21 memperlihatkan respon getaran pada arah horizontal muncul pada frekuensi 30, 45, 60, 75, dan $90 \mathrm{~Hz}$. Ini terjadi akibat dari keausan pada gudgeon-pin, silinder dan bantalan utama. Respon getaran pada arah horizontal dan vertikal yang menyatu muncul pada frekuensi pertama 1xrpm dengan magnitude $0,1 \mathrm{~m} / \mathrm{sec}^{2}$ pada arah vertikal. Pada Gambar 21 juga menunjukkan bahwa amplitudo terbesar terjadi pada frekuensi 15 dan $90 \mathrm{~Hz}$ dengan magnitude percepatan yang berbeda yaitu pada 0.12 dan $0.4 \mathrm{~m} / \mathrm{sec}^{2}$.

\section{KESIMPULAN}

Berdasarkan proses validasi maka celah bantalan utama, $\mathrm{C}_{1}=60 \mu \mathrm{m}$, nilai ini sesuai dengan hasil pengukuran celah pada proses reparasi terhadap mesin tersebut. Pemodelan ini dapat digunakan untuk prediktive maintenance berbasis pemantauan sinyal getaran yang terjadwal.

\section{DAFTAR PUSTAKA}

1. Maleev, V.L., and A.M., Bambang Priambodo, Operasi dan Pemeliharaan Mesin Diesel, Penerbit Erlangga, 1986.
2. Giancarlo G., Vibration of Structures and Machines, Dipartimento di Maccanica Politecnico di Torino Carco Duca Degli Abruzzi, 2410129 Torino, Italy, 1950.

3. Biezeno, C.B. and Grammel, R., Mesinering Dynamics, The book was first published in German in one volume entiled, Technische Dynamik, 1939.

4. Veritec A.S., Vibration Control in Ships, Noise and Vibration Group, Veritec, Marine Technology Consultants, 1985.

5. Astashev, V.K., Babitsky, V.I., and Kolovsky, M. Z., Dynamic and Control of Machines, CIP Data Applied for: Die Dwtsche Bibliothek, CIPEiaheitsaufnahme, New York, 2000.

6. Holowenko A.R., Dynamics of Machinery, Associate Professor of Mechanical Mesinering Purdue University, Wiley Trans-Edition, 1980.

7. Laboratorium Dinamika PPAU-IR ITB., Panduan Pelatihan Ilmu Getaran, Lab. Dinamika PPAU-IR Institut Teknologi Bandung, 2003.

8. Matlab \& Simulink Best Games \& Program Solution Guide for Windows Release 2009. 